\title{
TOP2A expression as the essential prognostic factor in lung neuroendocrine tumors
}

\author{
${ }^{1}$ Bogomolets National Medical University, Kyiv \\ ${ }^{2}$ Kyiv City Clinical Oncological Center \\ Одержано: 23.12.2021 \\ Прийнято до друку: 10.01.2022 \\ DOI: 10.32471/clinicaloncology.2663-466X.43-3.28396
}

\begin{abstract}
Summary. Lung neuroendocrine tumors (NETs) are considered rare, but their incidence increasing worldwide. According to recent studies, NETs take up to $\mathbf{2 5 \%}$ of all lung malignancies. Bronchopulmonary NETs are heterogeneous neoplasms classified into four histological types: typical carcinoid, atypical carcinoid, large cell neuroendocrine carcinoma and small cell lung carcinoma. Often lung NETs are clinically silent or cause non-specific symptoms; the correct diagnosis usually is delayed. Regional and distant metastasis turn out to be the first manifestation of the disease in more than $40 \%$ of patients, which has critically negative effect on the survival. Morphology and immunohistochemistry (IHC) are important in lung NETs diagnosis, but IHC results remains ambiguous in some cases. Ki-67 helps to distinguish carcinoids from high-grade lung NETs, but is not reliable enough to determine the disease clinical course and prognosis. The aim of this study was to evaluate expression of proliferative marker TOP2A as a prognostic criterion for lung NETs. Methods. Surgical and biopsy material from 50 patients with lung NETs before chemotherapy prescribing was used for this study. Regular morphological examination and IHC was performed in each case. Non-parametric statistics was used for Ki67 and TOP2A expression evaluation. Results. Higher Ki-67 scores corresponded to TOP2A higher expression (Spearman's correlation, $r=0.603, p=0.00000362$ ). There was no significant association of $\mathrm{Ki}-67$ and necrosis severity, and metastases. At the same time TOP2A expression related to several key features of lung NETs. TOP2A rates were significantly linked with necrosis severity and metastasis in lymph nodes. Low TOP2A scores were associated with longer overall survival (OS); a cutoff TOP $2 A \leq 13 \%$ was critical for patients' OS. Conclusions. TOP2A appeared to be more reliable than Ki-67 and can be used as the additional predictor for regional metastatic lesions at the time of diagnosis and for shorter survival rates in patients with lung NETs. But further prospective studies are desirable to clarify the "critical rates» of TOP2A as a prognostic factor at bronchopulmonary NETs.
\end{abstract}

Keywords: lung neuroendocrine tumors; immunohistochemistry; TOP2A; additional prognostic marker.

\section{INTRODUCTION}

The most modern research in oncology are focused on the study of clinical course, treatment, survival rates and outcomes, but all this is impossible without accurate and appropriate diagnostics. That is also actual for lung neuroendocrine tumors (NETs), that are considered heterogeneous malignancies, arising from neuroendocrine cells of the bronchopulmonary epithelium. Although NETs are uncommon (1-8 cases her 100000 in different countries), their incidence is rising over last decades, mainly because of greater awareness of the disease and increased accuracy of diagnosis [1-3].

Lung NETs account for only a small proportion of all cancers (about $0.5 \%$ ), and about $12 \%$ among all NETs, but their incidence has substantially increased over time $[1,3]$. Moreover, it is estimated that approximately $20-27 \%$ of all primary lung neoplasms are NETs [4]. In most cases lung NETs have no specific symptoms, and more than $95 \%$ of them are secretory inactive [5]. Because NET symptoms nonspecific or absent until more advanced stages, this often leads to a serious delay in diagnosis [1]. And there is a significant discrepancy between the number of NETs diagnosed clinically and morphologically. At the time of diagnosis more than $40 \%$ patients with lung NETs have local and distant metastases. If bronchopulmonary NETs manifest with distant metastases, the prognosis is critically poor: patients' OS is $8.3-11$ months [2,6]. Surgery is the method of choice in lung NETs' treatment, but after it, treatment options are limited: neither adjuvant chemotherapy no radiation therapy are standards of treatment of bronchopulmonary NETs $[3,7]$.

Lung NETs are divided into four morphological subtypes: from well-differentiated typical carcinoid (TC) to the high-grade large cell neuroendocrine carcinoma (LCNEC) and small cell lung carcinoma (SCLC), with extreme differences in management and survival $[3,8-12]$.
A major problem in neuroendocrine pathology is the identification and separation of aggressive low-grade NETs from those with a benign or more indolent behavior [13]. Morphological features are the «gold standard» for lung NETs grading, but practicing pathologists has experienced cases when clear-cut separation between TC and atypical carcinoid (AC) or AC and LCNEC using morphological criteria is impossible and additional tests are needed to reach a correct diagnosis and prognosis estimation [12].

Today, modified classification criteria include the number of mitoses per $2 \mathrm{~mm}^{2}$, the occurrence and severity of necrosis, histological features and IHC for neuroendocrine markers [7, 11, 14] (fig. 1).

$\mathrm{Ki}-67$ is mandatory for grading because grade is considered the dominant driver of prognosis in lung NETs [15-17]. Proliferative index is a potentially meaningful marker for lung NETs subcategorization, especially in biopsies with crash artifacts impairing the morphological evaluation [12]. Also, Ki-67 has been shown as a relevant prognostic factor in broncho-pulmonary NETs and it's high rate is significantly associated with clinical stages III and IV [18].

The correct diagnosis has critical influence on prognosis, but sometimes is difficult to make it accurately. And the significance of Ki-67 in lung NETs is still a controversial issue. Well differentiated lung NETs may show Ki-67 values that overlap with those of poordifferentiated, suggesting they have worse prognosis, than was established upon morphological features [3, 19]. That create some confusion among pathologists and clinicians. As Ki-67 evaluation is not considered reliable enough, especially in small biopsies and metastatic disease [16, 20,21], other cell proliferation markers, e.g. TOP2A may be used, although it's expression and prognostic effects seems different among different cancers [22, 23].

TOP2A is essential for the regulation of DNA topology during it's replication, transcription, and chromosome segregation and is strongly associated with cells proliferation especially 


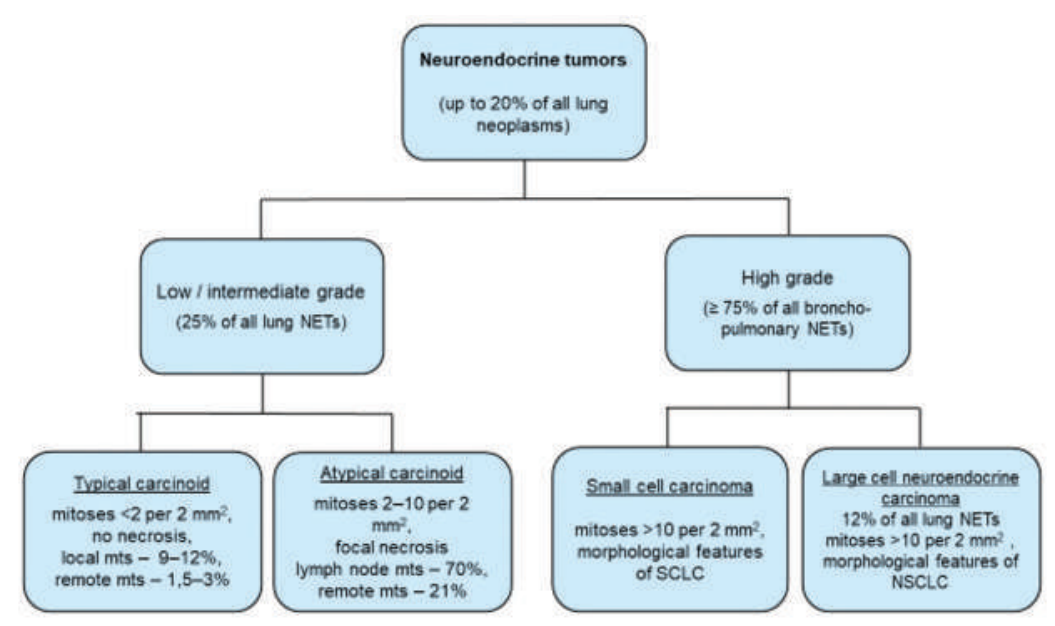

Fig. 1. Morphological criteria for the diagnostics of broncho-pulmonary NETs (adopted data) [3, 4]

in malignancies. TOP2A is considered as a marker giving valuable information on diagnosis at high and low differentiated tumors [24]. It was shown that increased expression of Ki-67 and TOP2A correlate with each other, and poor differentiation as well as grading, staging and prognosis [25]. Although these markers have different expression patterns in the cell cycle (Ki-67 shows the highest expression in G2/M phase, while TOP2A, mainly related to DNA synthesis - in the late S and G2-M phases), they are considered critical for evaluating the proliferation status and are a useful tool to assess the malignancy aggressiveness [26].

We aimed to estimate expression of TOP2A as the possible essential prognostic criterion for lung NETs.

\section{METHODS}

Retrospective and prospective study was conducted. FFPE blocks with lung NETs (resections and biopsies) were taken from 50 unique patients, have been treated in Kiev City Clinical Oncological Center in 2010-2020. Morphological diagnosis was made (including neuroendocrine morphology, grade, TNM, and stage). All the cases were classified based on 2015 WHO Thoracic Tumors Classification. Also, ICH was performed (neuroendocrine and lung tumors' markers: ChrA, Syn, TTF-1, CK7, CD56, Ki-67 and TOP2A) before chemotherapy was provided. All morphological and IHC data were assessed by two different independent pathologists without the knowledge of patient's clinical data. Medical records' data were used to assess clinical findings and survival.

The study was agreed with the Commission on Bioethical examination of Bogomolets National Medical University (protocol № 118, 18 Jan 2019).

To determine markers' expression, we used antiKi-67 monoclonal antibody, clone MIB-1 (Dako, USA), and Topoisomerase II alpha, Clone EP93 (Epitomics, France).

Only nuclear ICH staining and it's intensity for Ki67 and TOP2A was considered. For each sample, 5 microscopic fields at $\times 200$ magnification were selected, and 100 tumor cells in each field were counted to assess the staining intensity and percentage of positive cells.

$\mathrm{Ki}-67 \leqslant 3 \%$ was considered grade 1 (TC); Ki$674-19 \%$ corresponded grade 2 (AC); Ki-67 $\geqslant 20 \%$ was estimated as grade 3 (LCNEC and SCLC) [16, 17].

TOP2A expression was estimated on the same FFPE samples. We evaluated the correlation between TOP2A and Ki-67 rates. Also, we checked TOP2A association with necrosis severity and metastases. Patients' survival was evaluated depending on TOP2A rates.

All calculations were made using Microsoft Excel. Statistical analysis was performed using the Program EZR 1.35 (R statistical software version 3.4.3, R Foundation for Statistical Computing, Vienna, Austria).

We used nonparametric statistics for this study. Ki67 and TOP2A distribution was counted using Mann - Whitney U test. Spearman's rank correlation was used for Ki-67 and TOP2A levels association, and for TOP2A dependence on presence and severity of necrosis. ROC-curve was used to assess the prognostic value of TOP2A. Patients' survival was analyzed using Kaplan Meier method and monovariant Cox proportional hazard regression model. Log-rank test was used to assess the significance of differences in survival between groups with different TOP2A scores [27].

\section{RESULTS}

The patients' age ranged from 29 to 76 years, the male/female ratio was $4.55: 1$. There were $6(12 \%)$ patients $(4 \mathrm{M} / 2 \mathrm{~F})$ of young age $(15-47$ years old $) ; 22(44 \%)(16 \mathrm{M} / 6 \mathrm{~F})$ of the middle age (48-63 years old); and $22(44 \%)(21 \mathrm{M} / 1 \mathrm{~F})$ elderly patients $(\geqslant 64$ years old $)$.

The sample was censored. The follow-up period varied significantly - from 10 days to 7,1 years, on average, the observation period was 3.81 months. The outcome was not traced in $9(18 \%)$ cases. $12(24 \%)$ patients died, their OS after diagnosis averaged 2.41 months. Due to medical records, 29 (58\%) are alive; in this case the follow-up period also varied significantly and averaged 4.61 months.

At the time of diagnosis regional metastases of bronchopulmonary NETs were found in $36(72 \%)$ cases, distant metastases in $21(42 \%)$; in $6(12 \%)$ patients local or distant metastatic lesions were not identified. Distant metastases were seen in liver in $9(42.8 \%)$ cases, in bones - in 4 (19\%), in lungs - in $3(14.3 \%)$, in brain and joints - in $2(9.5 \%)$ observations each, in adrenal gland - in 1 (4.7\%) case. Multiple distant metastatic lesions were observed in $5(23.8 \%)$ cases. 7 patients $(33.3 \%)$ had distant metastases, but location is not clearly defined.

The pneumonectomy/lobectomy specimens were available in $18(36 \%)$ cases, others $32(64 \%)$ were biopsies; $16(50 \%)$ biopsies were small, with extensive crush artifact.

All examined cases showed features of neuroendocrine architecture: «nests», «rosettes» or trabeculae and were positive for one or more neuroendocrine markers, other than NSE. Based upon diagnostics criteria, there was 1 (2\%) TC, 17 (34\%) AC, 7 (14\%) LCNEC, and 25 (50\%) specimens were SCLC.

The examples of Grade 2 and Grade 3 lung NETs morphology, Ki-67 and TOP2A expression are presented on fig. 2-7, and in the table.

We observed a strong correlation between nuclear $\mathrm{Ki}-$ 67 and TOP2A staining intensity and a percentage of positive sells (Spearman's correlation, $\mathrm{r}=0.603, \mathrm{p}=0.00000362$ ).

$\mathrm{Ki}-67$ scores ranged within $2-100 \%$. Ki-67 $\leqslant 3 \%$ was observed just in $1(2 \%)$ tumor sample; Ki-67 4-19\% - in $18(36 \%)$; Ki-67 $\geqslant 20 \%-$ 


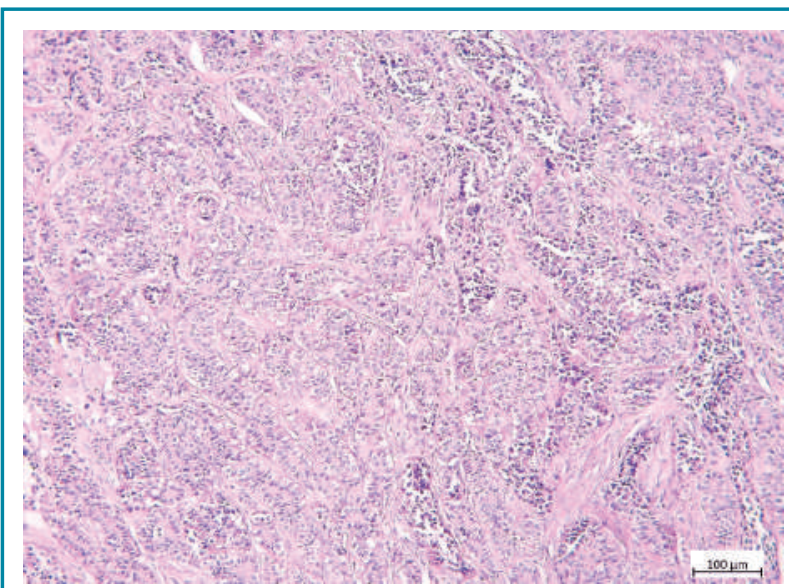

Fig. 2. Lung NET, Grade 2, mainly solid type of growth with «nests» of tumor cells in fibrotic areas, and single small foci of necrosis. Stained H\&E, $\times 200$

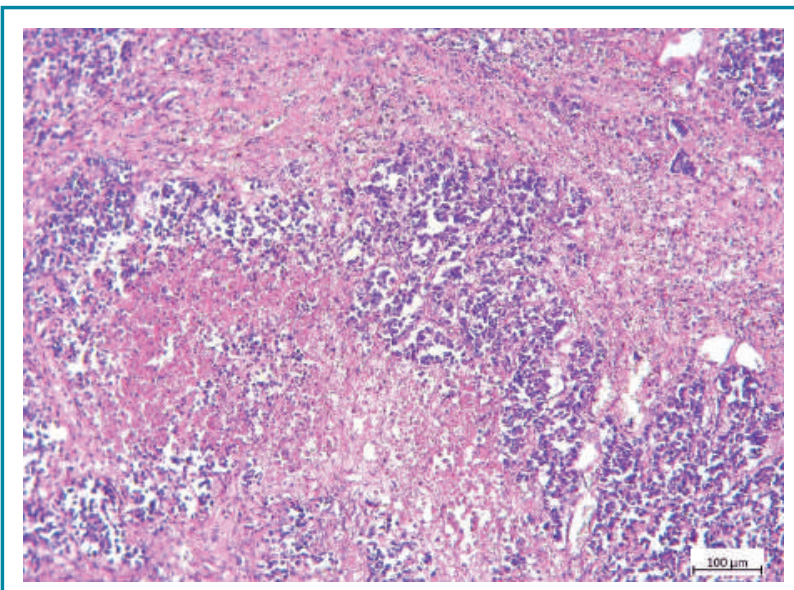

Fig. 3. Pulmonary NET Grade 3 with numerous severe necroses and hemorrhages. Stained H\&E, $\times 200$

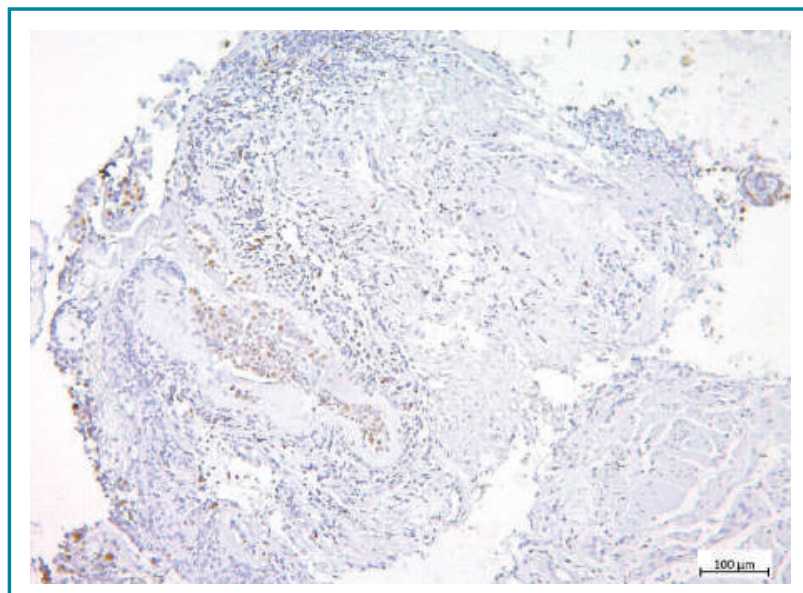

Fig. 4. IHC. Ki-67 focal nuclear staining (15\%) in lung NET Grade 2, ×200

in $31(62 \%)$ cases. Necrosis was seen in $37(74 \%)$ tumor samples, and in $21(42 \%)$ cases it was severe. The mean Ki-67 in patients without necrosis was $30.8 \%$ (ranged 2-80\%) (95\% CI 16-45\%). In cases with necrosis the mean Ki-67 was $37.3 \%$ (ranged 4-100\%) (95\% CI 29$46 \%$ ). The difference between these two groups (without necroses and with necrotic foci) was significant (Mann - Whitney test, $\mathrm{p}=0.02$ ). Modified classification for lung NETs diagnostics includes

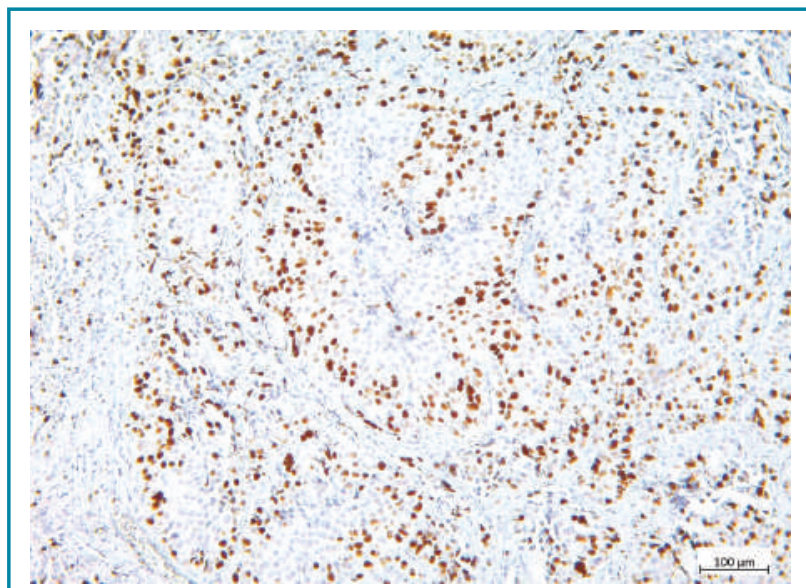

Fig. 5. IHC. Ki-67 diffuse nuclear staining (60\%) in lung NET Grade 3, ×200

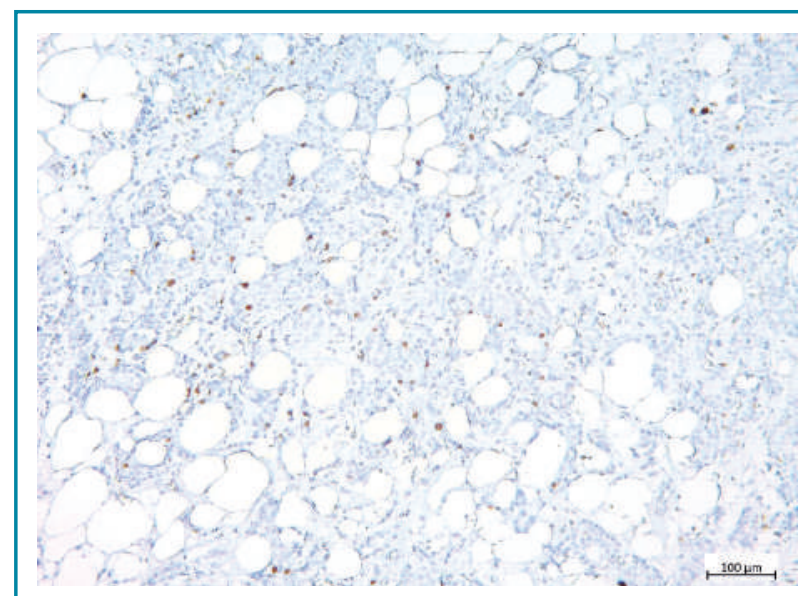

Fig. 6. IHC. TOP2A low expression (7\%) in bronchopulmonary NET Grade 2, ×200

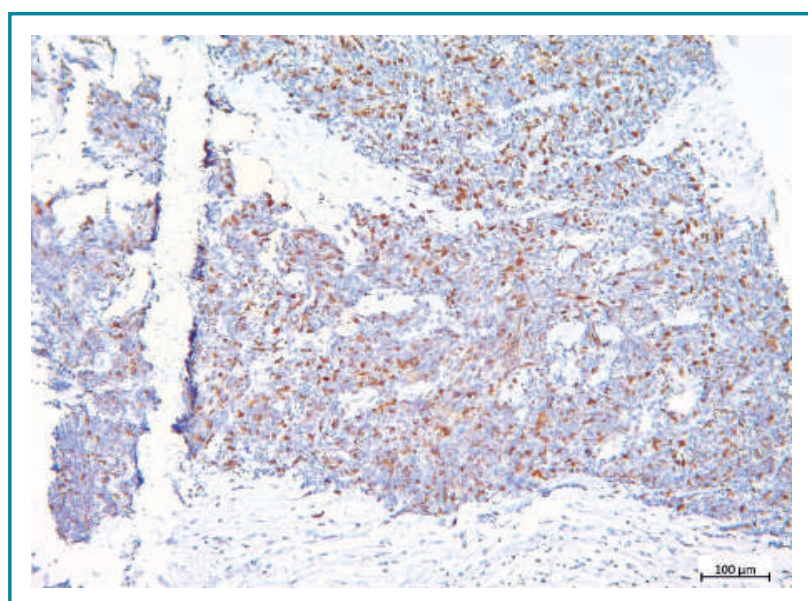

Fig. 7. IHC. High TOP2A expression, diffuse nuclear staining $(65 \%)$ in lung NET Grade $3, \times 200$

$\mathrm{Ki}-67$ rates and necrosis characteristics. It is considered that lung NETs Grade 2 perform several small foci of necrosis, while in Grade 3 malignancies necrotic areas are usually extended and accompanied by massive hemorrhages. However, in the current study Ki-67 expression didn't show relations with necrosis severity (Spearman's correlation, $\mathrm{p}=0.078$; Mann - Whitney test, $\mathrm{p}=0.316$ ).

Data on TOP2A rates and their estimation are rather contradictory. Different authors propose wide range of TOP2A cut- 
Table. Ki-67, TOP2A, necrosis and metastasis in lung NETs Grade 2 and Grade 3*

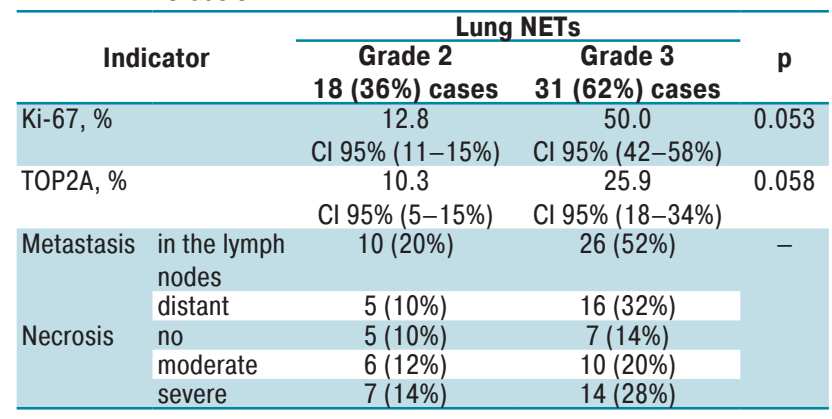

${ }^{*}$ One case - patient with TC (T2NOM0, stage IB), Ki-67 $=2 \%$, TOP2A $=0 \%$ wasn't included in the table.

offs, but mainly they are $\geqslant 30 \%$ [22]. In our study TOP2A expression was quite heterogeneous (it ranged from 0 to $85 \%$ ). TOP2A $\geqslant 5 \%$ was considered positive in $38(76 \%)$ cases; TOP2A $\geqslant 35 \%$ was estimated as overexpression in $10(20 \%)$ cases. In $8(16 \%)$ samples TOP2A rates did not exceed 5\%; $4(8 \%)$ observations showed negative TOP2A staining. The mean TOPA score for positive expression was $25.6 \%$ (95\% CI 20-32\%); for overexpression - 51.9\% (95\% CI 41$63 \%$ ); and $1.75 \%$ (95\% CI 1-2\%) if TOP2A rates didn't exceed $5 \%$. TOP2A expression appeared to be significantly associated with the presence of necrosis (Spearman's correlation, $\mathrm{r}=0.318$, $\mathrm{p}=0.0242)$ and it's severity $(\mathrm{r}=0.303, \mathrm{p}=0.0323)$.

Although Ki-67 rates increased in tumors with necrotic arears, necrosis severity didn't affect the level of Ki-67 expression. There was no significant dependence of $\mathrm{Ki}-67$ expression and metastases. At the same time TOP2A expression related to several key points of lung NETs (presence of necrosis ant it's severity and lymph node metastases). The significant, linear, straight correlation between Ki67 and TOP2A expression was revealed (Spearman's correlation, $\mathrm{r}=0.603, \mathrm{p}=0.00000362)$. Higher rates of $\mathrm{Ki}-67$ corresponded to larger expression of TOP2A.

Degree of lymph nodes involvement is a prognostic factor at the most common NETs sites; it's higher rates are associated with poor prognosis $[3,5,28]$. At the time of diagnosis metastases into lymph nodes were seen in $36(72 \%)$ patients, and in $8(16 \%)$ cases lymphoma was clinically suspected.

We estimated the predictive value of TOP2A scores for lymph node lesion at the time of diagnosis (fig. 8, 9).

TOP2A rates $>13 \%$ was a prognostic factor for lymph nodes metastatic lesion, at TOP $2 \mathrm{~A} \leqslant 13 \%$ metastases in the lymph nodes as a rule were not found (prognosis sensitivity $64 \%$, specificity $73 \%$ ).

TOP2A as a quantitative variable had a statistically significant effect on survival (Cox regression, Hazard Ratio 1.038; 95\% CI: $1.005-1.073$, p=0.024), while Ki-67 showed no effect

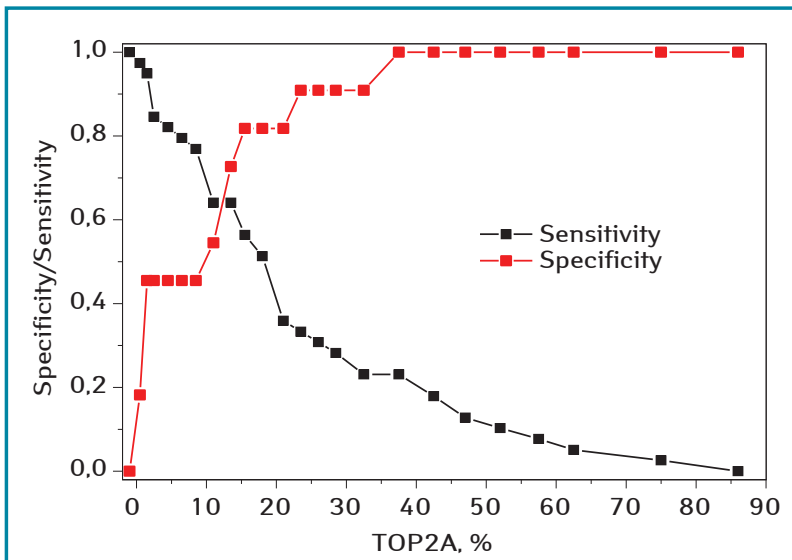

Fig. 8. Sensitivity and specificity of regional metastases prediction depending on the rates of TOP2A $(\mathrm{p}=0.106)$. Using Kaplan - Meier estimator, the median survival in the entire sample range was 14 months (95\% CI 6-21 months); one-year survival was $58 \%$. The sample range was divided into 2 groups for comparison: $23(46 \%)$ cases at TOP2A rates $\leqslant 13 \%$ and $27(54 \%)$ cases at TOP2A $>13 \%$ (according to obtained data on TOP2A scores as a predictor for lymph nodes metastatic lesion). The patients' survival was significantly different in these 2 groups (log-rank test, $p=0.006)$. The median survival at TOP $2 A \leqslant 13 \%$ was 45 months, at TOP2A $>13 \%$ - only 8 months; one-year survival was $100 \%$ and $39 \%$ respectively (fig. 10 ).

\section{DISCUSSION}

Lung NETs are rare, heterogeneous group of neoplasms, but their incidence has steady risen over the past few decades which makes it necessary to revise and optimize criteria for their diagnosis and prognosis that can be used in everyday practice of pathologists.

$\mathrm{Ki}-67$ is widely used and is considered «the diagnostics golden standard» $[13,16]$, however it is not reliable in the case of lung NETs and cannot be used as a prognostic marker at least for metastatic disease and survival. We used an additional proliferative marker TOP2A for more accurate prognosis evaluation at pulmonary NETs'. TOP2A is a marker of tumor cells proliferation, it may show strong correlation with the neoplasia biology and predict

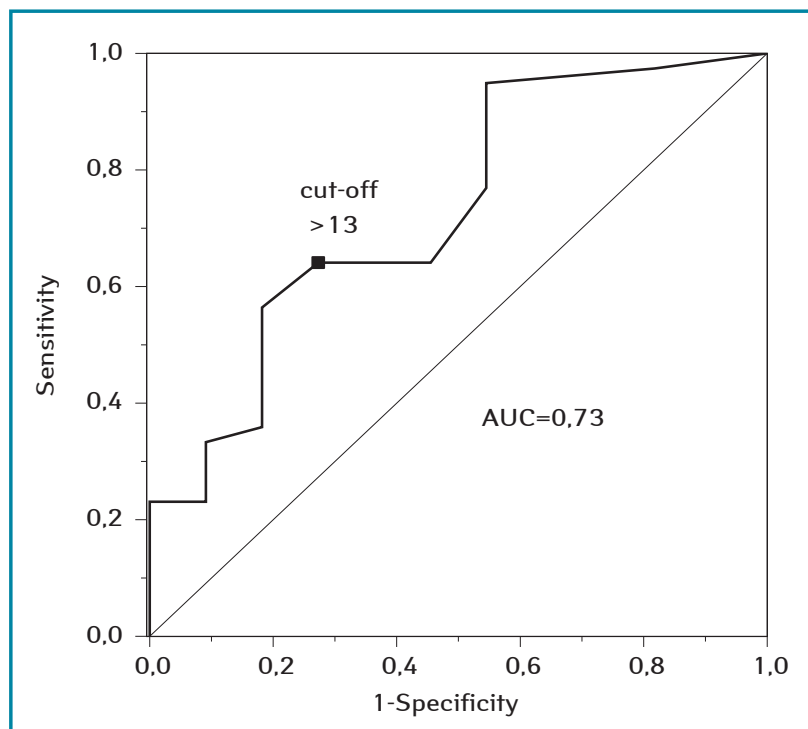

Fig. 9. This is a good $R O C$ curve $(A \cup C=0.73)$ : diagnostic test for lymph node metastases depending on TOP2A scores

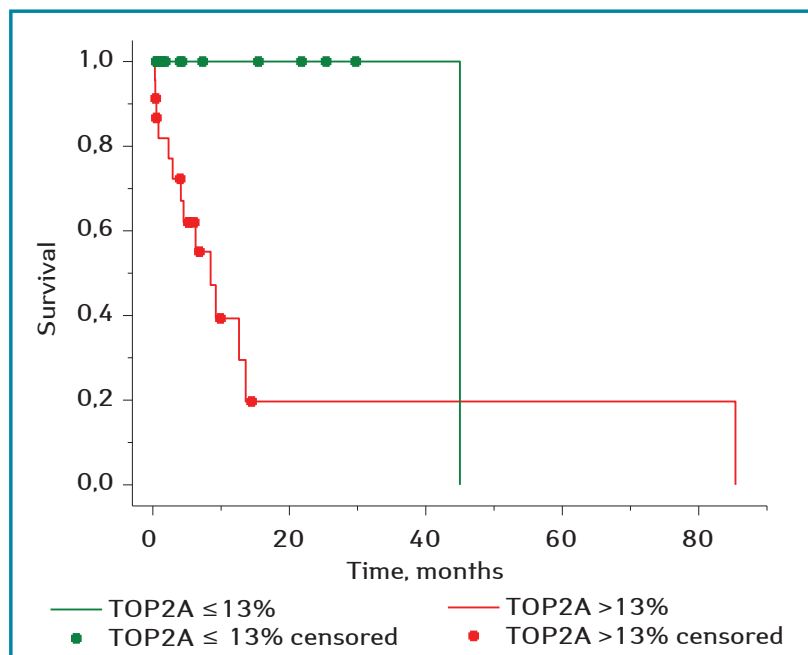

Fig. 10. The OS varied significantly at TOP $2 A$ rates $\leqslant 13 \%$ and $>13 \%$ (log-rank test, $p=0.006$ ) 
it's clinical course [22]. TOP2A is not a new marker in cancer studies, but the majority of them are focused on it's potential predictive value for anthracyclines efficacy $[22,24]$. Although, there were several attempts to use TOP2A to predict the course of the disease (presence of metastases) or survival rates in different cancers, but results appeared to be quite contradictory. One of probable reasons may be due to different prognostic impact of TOP2A in different types and subtypes of cancer. Another one mainly due to different methods used to detect TOP2A status in different studies (usually FISH and $\mathrm{ICH}$, and poor agreement between these two methods) $[22,26]$. Currently, ICH is commonly used method to detect TOP2A. But till now no standard antibodies, staining procedure, and scoring system have been recommended. Various cut-off values such as $5 \%, 10 \%$, $15 \%, 20 \%$ and $30 \%$ have been applied in different studies [22].

Our study showed TOP2A is significantly associated with high Ki-67 index, suggesting that such lung NETs are more aggressive. All cases of TOP2A overexpression $(\geqslant 35 \%)$ corresponded to Grade 3, mean Ki-67 index was 57\% (95\% CI 35-79\%).

TOP2A expression, in contrast to $\mathrm{Ki}-67$, was significantly associated not only with necrosis, but also with its severity and with lymph node metastases. According to literature, at bronchopulmonary NETs metastatic lesion of regional lymph nodes has the worst predictive value than histology of the neoplasia [28].

The prognostic significance of TOP2A increased rates for regional metastases and survival was shown (good ROC curve $(\mathrm{AUC}=0.73 ; 95 \% \mathrm{CI}: 0.558-0.901)$. For TOP $2 \mathrm{~A} \leqslant 13 \%$ metastases in the lymph nodes were not typical; median life expectancy was 45 months, one-year survival reached $100 \%$. While TOP2A index $>13 \%$ was a predictive factor for lymph nodes metastatic lesion at the time of diagnosis and significantly poor prognosis: median OS was about 8 months, one-year survival did not exceed $39 \%$.

These data lead us to the following suggestions: first one that TOP2A is more sensitive than Ki-67 and can be used as an additional predictive marker for lymph node metastases in lung NETs; another one is that TOP2A can be thought as a prognostic factor, it's higher scores are associated with poor survival.

\section{CONCLUSIONS}

The current study demonstrated the prognostic impact of TOP2A expression in lung NETs, suggesting the potential value of TOP2A as a reference to regional metastatic lesions and shorter survival rates.

Limitation of the current study: retrospective analysis, and relatively small sample range, the outcome could not be traced in all the cases. Some patients were prescribed the adjuvant chemotherapy (different drugs in different regimens) that could affected their lifespan, so it also was acknowledged as a limiting factor for this study.

Further prospective studies with standardized methods of TOP2A measuring are needed to overcome the mentioned limitations and to clarify the «critical rates» of TOP2A as a prognostic factor in bronchopulmonary NETs.

Financing. The current study was performed as part of research work «Development of histological and molecular-biological criteria for differential diagnosis of tumors and precancerous changes in organs and their prognostic value» (state registration № 0119U101131).

The authors have no conflict of interest to declare.

\section{REFERENCES}

1. Singh S., Granberg D., \& Wolin E. (2016). Patient-reported burden of a neuroendocrine tumor (NET) diagnosis: results from the first global survey of patients with NETs. Journal of global oncology, 3(1), 43-53. doi: 10.1200/JGO.2015.002980.

2. Darba J., \& Marsa A. (2019). Exploring the current status of neuroendocrine tumors: a population-based analysis of epidemiology, management and use of resources. BMC Cancer, 19(1), 1226. doi: 10.1186/s12885-019-6412-8.

3. Hendifar A. E., Marchevsky A. M., \& Tuli R. (2017). Neuroendocrine tumors of the lung: current challenges and anvances in the diagnosis and management of well-differentiated disease. Journal of thoracic oncology, 12(3), 425-436. doi: $10.1016 / \mathrm{j}$.jtho.2016.11.2222.

4. Tsoukalas N., Baxevanos P., Aravantinou-Fatorou E., Tolia M. Galanopoulos M., Tsapakidis K., \& Kyrgias G. (2018). Neuroendocrine tumors of the lung. Annals of translational medicine, 6(8), 146. doi:10.21037/atm.2018.04.03.
5. Oronsky B., Patrick C. M., \& Morgensztern D. (2017). Nothing but NET: a review of neuroendocrine tumors and carcinomas. Neolasia, 19(12), 991-1002. doi: 10.1016/j.neo.2017.09.002.

6. Riihimaki M., Hemminki A., \& Sundquist K. (2016). The epidemiology of metastases in neuroendocrine tumors. International journal of cancer, 139(12), 2679-2686. doi: $10.1002 /$ ijc.30400.

7. Sadowski S. M., Christ E., \& Bedat B. (2018). Nationwide multicenter study on the management of pulmonary neuroendocrine (carcinoid) tumors. Endocrine connection, 7(1), 8-15. doi: 10.1530/EC-17-0271.

8. Hung Y. P. (2019). Neuroendocrine tumors of the lung: updates and diagnostic pitfalls. Surgical pathology clinics, 124(4), 1055-1071. doi: 10.1016/j.path.2019.08.012.

9. Cros J., Theou-Anton N., Gounant V., Nicolle R., Reyes C., Humez S. \& HescotS. (2021). Specific genomic alterations in high-grade pulmonary neuroendocrine tumors with carcinoid morphology. Neuroendocrinology, 111(1-2), 158-169. doi: 10.1159/000506292.

10. Borczuk A. C. (2020). Pulmonary neuroendocrine tumors. Surgical pathology clinics, 13(1), 35-55. doi: 10.1016/j.path.2019.10.002.

11. Saber M., Ismail Y., \& Alieldin N. (2018). Neuroendocrine tumors of the lung: A five-year retrospective experience of Egyptian $\mathrm{NCl}$ (2010-2014). Journal of the Egyptian National Cancer Institute, 30(4), 151-158. doi: 10.1016/j.jnci.2018.10.005.

12. La Rosa S., \& Uccella S. (2021). Classification of neuroendocrine neoplasms: lights and shadows. Reviews in endocrine and metabolic disorders, 22(3), 527-538. doi:10.1007/s11154-020-09612-2.

13. Jackson A. S., Rosental A., Cattoni M., Bograd A. J., Farivar A. S., Aye R. W. \& Vallieres E. (2020). A staging system for neuroendocrine tumors of the lung needs to incorporate histological grade. The Annals of thoracic surgery, 109(4), 1009-1018. doi: 10.1016/j.athocarsur.2019.09.053.

14. Righi L., Gatti G., Volante M., \& Papotti M. (2017). Lung neuroendocrine tumors: pathological characteristics. Journal of thoracic disease, 9(15), S1442-S1447. doi:10.21037/jtd.2017.01.59.

15. Gupta S., Gupta P., Rohilla M., Gupta N., Srinivasan R., Rajwanshi A., \& Saikia U. N. (2020) Neuroendocrine carcinomas: cytological mimics and diagnostic dilemmas. Diagnostic cytopathology, 48(5), 440-445. doi: 10.1002/dc.24386.

16. Garg R., Bal A., Das A., Singh N., \& Singh H. (2019). Proliferation marker (Ki-67) in sub-categorization of neuroendocrine tumors of the lung. Turk Patholoji Derg, 35(1), 15-21. doi: 10.5146/tjpath.2018.01436.

17. Naheed S., Holden C., \& Tanno L. (2019). The utility of Ki-67 as a prognostic biomarker in pulmonary neuroendocrine tumors: protocol for a systematic review and meta-analysis. BMJ Open, 9(8), e031531. doi:10/1136/bmjopen-2019-031531.

18. Neubauer E., Wirtz R. M., \& Kaemmerer D. (2016). Comparative evaluation of three proliferation markers, Ki-67, TOP2AA, and RacGAP1 in bronchopulmonary neuroendocrine neoplasms: issues and prospects. Oncotarget, 7(27), 1959-1973. doi: $10.18632 /$ oncotarget.9747

19. Kasajima A., Konukiewitz B., Oka N., Suzuki H., Sakurada A., Okada Y. \& Kameya T. (2019). Clinicopathological profiling of lung carcinoids with Ki-67 index $>20$. Neuroendocrinology, 108(2), 109-120. doi: 10.1159/000495806.

20. Marchio C., Gatti G., MassaF., Bertero L., Filosso P., PelosiG., \& Cassoni P. (2017). Distinctive pathological and clinical features of lung carcinoids with high proliferation index. Virchows Arch, 471(6), 713-720. doi:10.1007/s00428-017-2177-0.

21. Boland J. M., Kroneman T. N., Jenkins S. M., Terra S. B. S .P., Xie H., Molina J., \& Mounajjed T. (2020). Ki-67 labeling index in pulmonary carcinoid tumors: comparison between small biopsy and resection using tumor tracing and Hot spot methods. Archives of pathology \& laboratory medicine, 144(8), 982-990. https://doi.org/10.5858/arpa.2019-0374-OA.

22. An X., Xu F., Luo R., Zheng Q., Lu J., Yang Y., \& Qin T. (2018). The prognostic significance of topoisomerase II alpha protein in early stage luminal breast cancer. BMC Cancer, 18(1), 331. doi:10.1186/s12885-018-4170-7.

23. Cai H., Shao B., Zhou Y., \& Chen Z. (2020). High expression of TOP2AA in hepatocellular carcinoma is associated with disease progression and poor prognosis. Oncology Letters, 20(5), 232. doi:10.3892/ol.2020.12095.

24. Lotz C., \& Lamour V. (2020). The interplay between DNA topoisomerase $2 a$ post-translational modifications and drug resistance. Cancer drug resistance, 3, 149-160. doi:10.20517/cdr.2019.114.

25. Yatabe Y., Dacic S., Borczuk A. C., Warth A., Russell P. A., Lantuejoul S., \& Beasley M. B. (2019). Best practices recommendations for diagnostic immunohistochemistry in lung cancer. Journal of thoracic oncology, 14(3), 377-407. doi: $10.1016 /$ i.tho.2018.12.005

26. Niotis A., Tsiambas E., Fotiades P. P., \& Ragos V. (2018). Ki67 and Topoisomerase lla proliferation markers in colon adenocarcinoma. J BUON, 12(7): $24-27$

27. Gur'yanov V. G., Lyakh Yu. E., \& Parii V. D. (2018). Posibnik z biostatistiki. Analiz rezul'tativ medichnikh doslidzhen' u paketi EZR(R-STATISTICS) / Navchal'nii posibnik. [in Ukr.]. Handbook on biostatistics. Analysis of the results of medical research in the EZR package (R-STATISTICS). Kyiv: Vistka, $206 \mathrm{p}$

28. Cardillo G., Sera F., \& Martino M. (2004). Bronchial carcinoid tumors: nodal status and long-term survival after resection. The Annals of thoracic surgery, 2004, 77(5), 1781-1785. doi: 10.1016/j.athoracsur.2003.10.089.

\section{Експресія ТОР2А як суттєвий прогностичний фактор при нейроендокринних пухлинах легень}

Г.С. Читаєва ${ }^{1}$ Л.М. Захариева ${ }^{1,2}$

${ }^{1}$ Національний медичний університет імені Богомольця, Київ ${ }^{2}$ Київський міський клінічний онкологічний центр

Резюме. Нейроендокринні пухлини (НЕП) легені вважаються досить рідкісними, проте захворюваність на НЕП зростає в усьому світі. За даними нещодавніх досліджень, НЕП становлять до 25\% у структурі всіх новоутворень легені. НЕП бронхолегеневої локалізації - гетерогенні новоутворення, які розподіляють на 4 гістологічних типи: типовий карциноїд, атиповий карциноїд, крупноклітинна нейроендокринна карцинома та дрібноклітинна карцинома легені. Нерідко НЕП легень є клінічно «мовчазними» або харак- 


\section{Оригінальні статті / Original Articles}

теризуються неспецифічними симптомами; встановлення коректного діагнозу зазвичай відтерміновується. Регіонарні та віддалені метастази виявляються з першим клінічним проявом захворювання більш ніж у $40 \%$ пацієнтів, що вкрай негативно позначається на виживаності. Морфологічне та імуногістохімічне (ІГХ) дослідження важливі для діагностики НЕП легені, однак результати ІГХ дослідження у деяких випадках складно трактувати однозначно. Ki-67 допомагає відрізнити карциноїди від більш низько диференційованих НЕП, однак це недостатньо надійний маркер для визначення клінічного перебігу захворювання та прогнозу. Мета дослідження: оцінка експресії проліферативного маркера ТОР2А як прогностичного критерію при НЕП легені. Методи. Для проведення дослідження використано операційний і біопсійний матеріал, отриманий від 50 хворих при НЕП легені до призначення їм хіміотерапії. У кожному з випадків проведене морфологічне та ІГХ дослідження. Для оцінки експресії Ki-67 і ТОР2А використано методи непараметричної статистики. Результати. Більш високий показник Кі-67 відповідав вищому рівню експресії ТОР2А (коефіцієнт кореляції Спірмена, $\mathrm{r}=0,603$, $\mathrm{p}=0,00000362$ ). Не виявлено достовірного зв'язку між рівнем експресії Кi-67 та вираженістю некрозу, а також наявністю метастазів. Натомість експресія ТОР2А була пов'язана з кількома ключовими особливостями НЕП легені. Виявлено достовірний зв'язок між рівнем ТОР2А і вираженістю некрозу, а також метастатичним ураженням лімфатичних вузлів. Низькі показники ТОР2А асоціювалися з більшою тривалістю життя; порогове значення ТОР $2 \mathrm{~A} \leqslant 13 \%$ було критичним для виживаності пацієнтів. Висновки. Рівень експресії ТОР2А - більш надійний показник, ніж Кі-67, і може бути використаний у якості додаткового предиктора наявності регіонарних метастазів на момент встановлення діагнозу та скорочення тривалості життя пацієнтів при НЕП легені. У подальшому бажано проведення проспективних досліджень для уточнення «критичних показників» ТОР2А як прогностичного фактора при бронхолегеневих НЕП.

Ключові слова: нейроендокринні пухлини легені; імуногістохімія; ТОР2А, додатковий прогностичний маркер.

Correspondence:

Chytaieva Halyna

4/208 M. Rokossovsky Av., Kyiv, 04201

E-mail:h.chytaieva@gmail.com 